\title{
RECLAIMING CUBAN CULTURAL IDENTITY WHILE LIVING AS A CUBAN DIASPORA IN AMERICA AS DEPICTED IN CAMILA CABELLO "HAVANA"
}

\author{
Tan Michael Chandra \\ tan.michaelc@gmail.com \\ Graduate Program in English Language Studies \\ Sanata Dharma University, Yogyakarta, Indonesia
}

\begin{abstract}
Question of identity remains one of the most important and debatable concept in the world of postcolonial theory especially when it is related to cultural identity of the diaspora. As culture is intertwined with place of origin, diasporic community often experience difficulty to identify themselves as they are located outside their culture of origin.By using Hall's Cultural Identity, Bhabha's Hybridity, and Historical Biographical approach, this paper shall dissect such notion of reclaiming the diasporic's own culture as depicted in Camila Cabello's most famous song "Havana." Upon closer scrutiny, what at first glance considered as a simple love song underlines the cultural notion behind it. As the singer and songwriter is Cuban, Cabello expresses a theme of longing and stake a claim of Cuban cultural identity in the character of the song despite being offered a life in America. This perspective is highlighted through essay from Cabello herself, which notes the notion of cultural exchange and the life of the immigrants
\end{abstract}

Keywords: Cultural Identity, Hybridity, Havana, Camila Cabello

\section{INTRODUCTION}

Cultural issue as a result of colonization is one of the important issues that is tackled by postcolonial theory. One of the cultural issues that is very popular and problematic in the same time is the issue of identity, especially cultural identity. Cultural identity refers to how someone perceived themselves or perceived by someone else as a part of certain culture. Because the nature of the human as social creature, this issue is very important for human to feel that he or she belongs to some group of culture. However, the issue becomes problematic when it is related with colonization and the aftermath. Colonization heavily shapes and alters culture heavily and also affects the people withheld those culture. Many of the natives have feel that they lost their authentic culture because of the colonization in their area while many others are not only lost their culture but need to immigrate and living to different places from their origin. The latter experience is called diaspora.

One problem of becoming diaspora is the unfamiliar experience from their current place as they come from places with different culture, tradition and history.
The more people from different places from into the place, the more complicated the issues. As people from different place has different culture, the issue of cultural identity becoming a problematic issue among the diasporic community. Longing of their places of origin and being alienated in the places of their proximity often occurs.

To better contextualize the question of cultural identity within diasporic community, this paper analyzes the song "Havana" by Camila Cabello as become the object of the study of this research. The song explores the situation of a girl who is longing to come back to her homeplace, Havana, despite already settled in United States. Moreover, this paper also foregrounds the singer's essay as the secondary data. The singer's essay enriches the discussion about how cultural identity is not something closely linked with the place of origin and can be attributed to our present situation.

As the issue of cultural identity becomes the main emphasis of this paper, a theory about it shall be discussed in this part. The discourse of identity in the scope of postcolonial theory is never ever been simple, especially due to the relation of colonizer and colonized. Some scholar 
believe identity is something singular, a unitary-essentialized thing that a person has to differentiate him or her with the others. In the notion of cultural identity of the diaspora however, things cannot be that simple. As cultural identity usually related to the current places of someone's inhabitation it becomes problematic and confusing whether applied to a diasporic community. Due to their experience of being uprooted from their place of origin, diasporic always longing for their cultural identity while in the same time being questioning and questioned whether they are still within the realm of their past ancestor culture when they are not in their native land. This situation calls for another view concerning a singular identity and instead asserting that identity instead is a never-complete production and thus made us stay in the state "becoming."

One foremost scholar of identity in diasporic community is Stuart Hall. He asserts that identity always in the process of becoming, and never complete. In his opinion,

identity is not as transparent or unproblematic as we think. Perhaps instead of thinking of identity as an already accomplished fact, which the new cultural practices then represent, we should think, instead, of identity as a 'production', which is never complete, always in process, and always constituted within, not outside, representation. This view problematizes the very authority and authenticity to which the term, 'cultural identity', lays claim. (Hall, 2015:392)

Hall emphasizes the ever-changing nature of identity that can never-become finished as long as the human's lifespan remains. Through his remark, Hall notes that the diasporic people are one example of the notion of ever-changing identity. He notes that in Caribbean, as he originates from Caribbean himself, a unique condition happened. People from Caribbean came from many places as the result of slavery, force labor, and immigration. Therefore, it is very hard to speak for universal "one" identity as a Caribbean as majority of the people is not originated from there as they are basically people come from Africa, Europe, and even Asia. This is why Hall remarks that

We cannot speak for very long, with any exactness, about 'one experience, one identity', without acknowledging its other side - the ruptures and discontinuities which constitute, precisely, the Caribbean's 'uniqueness' (Hall, 2015:395).

Hall advises that the essentialization of identity and experience is not advisable due to the different origins of the people who now become the people of Caribbean. The people also have no access anymore toward their native culture of their ancient land and thus needs to craft a new cultural identity by also negotiating and adding the fact of the similar experience of colonization that they shared between them.

From his experience as a Caribbean, Hall stresses that identity as something that is always in the state of "becoming". He argues that people identifies themselves as belong into nowadays might differ in next few years due to the different cultural phenomena. Continuing his argument, Hall remarks about there is no singular experience and one identity when negotiating cultural identity, remarking that the notion of identity is always plural, a way of thinking that he draws a similar concern with Homi K. Bhabha. Bhabha remarks that cultures are never unitary in themselves, nor simply dualistic in relation of Self to Other. (Bhabha, 2003:207). From this sentence it shows that not only Bhabha agrees with Stuart Hall's remarks that culture is never unitary, he also added that culture has inclination to influence each other. The culture always enunciates with each other, each influence each other while in the same time always in the state of "becoming." Bhabha states that, it is only when we understand that all cultural statements and systems 


\begin{abstract}
are constructed in this contradictory and ambivalent space of enunciation, that we begin to understand why hierarchical claims to the inherent originality or 'purity' of cultures are untenable, even before we resort to empirical historical instances that demonstrate their hybridity. (Bhabha, 2003:208)
\end{abstract}

Bhabha argues that because the cultures between the people keep influencing on each other, there is no more authentic culture within the scope of colonized country like Caribbean. He criticizes the search for "pure-untainted culture" or the pre-colonial past and instead assert the necessity in the ambivalence of culture enunciation. From Bhabha and Hall, it can be concluded how should a diasporic citizen seek to understand their search of cultural identity. By seeing that they have multiple identities as a result of enunciation between each other culture and learn to live with the hybridity that exist in their cultural discourse.

This research also employs
historical

Biographical criticism is a form of literary criticism which analyzes a writer's biography to show the relationship between the author's life and their works of literature (Griffith, 2004:177-178) or a critical method that "sees a literary work chiefly, if not exclusively, as a reflection of its author's life and times (Guerin, 2005:51). To rephrase, the researcher who employs this criticism tries to see the connection between the authors' own experience in life with the works that they write in the form of theme, setting, or event that is exist in the literary works. This paper shall use this criticism, deriving from the essays written by Camila Cabello combined with the cultural identity originated from postcolonial criticism in order to dissect the underlying notion in the object of the study.

\section{DISCUSSIONS}

\section{Song Analysis: Reclaiming Cuban Cultural Identity}

The song "Havana" by Camila Cabello has a generic pop-song structure though it has peculiarity in starting the song not with the verses but chorus instead. The structure of the song is chorus, verse 1, pre-chorus, chorus, verse 2 , pre-chorus, chorus, bridge and then a last chorus. There are two versions of the song, one of them is the version released worldwide featuring a rapper Young Thug and thus having his rap verse. The other one is the no-rap version that Cabello mostly perform in front of the audience as the rapper is not always available. Cabello changes the second verse, which contain a rap verse from Young Thug in original version, with her own lyric while still following the theme of the song. This research shall explores the no-rap version of the songs

First things to analyze is the verses, the first verse consists of these lines.

He didn't walk up with that "how you doin'?" (uh)

(When he came in the room)

He said there's a lot of girls I can do with (uh)

(But I can't without you)

I knew him forever in a minute (hey)

(That summer night in June)

And papa says he got malo in him (uh)

He got me feelin' like

The first verse explores how the speaker of the song - a woman- meet a man that immediately she falls in love for. It can be implied that the man is a rebellious and womanizer ("He said there's a lot of girls I can do with") and also not a good man in the view of older person ("And papa says he got malo in him") as "malo" is Spanish word for evil. Therefore, this means that the man who approach the speaker is not a completely good man. The speaker falls for him anyway and their adventure can be seen in second verse 
I knew I was there when I read the sign

(Welcome to La Yuma)

I knew it was him when he hugged

from behind

(It gets me every time)

He's put in work, but it's in the streets

(He said, girl, can you ride?)

And this is the part that my daddy told me

He got me feelin' like

The second verse implies that the girl follows the man to live in America. The notion can be seen in the lyric of "Welcome to La Yuma" because La Yuma is Cuban street lingo for the United States. This means that the girl follows the man and leaves her hometown Cuba to United States. However, the relationship does not work well as the girl realized that the man is having bad intention to her (He's put in work, but it's in the streets, He said, girl, can you ride?) also because the girl has different feeling of love as she does not completely devotes herself to the man. It can be seen in the pre-chorus of the songs

Oooh... I knew it when I met him

I loved him when I left him

Got me feelin' like

Oooh... and then I had to tell him

I had to go, oh na-na-na-na-na

This part shows how the girl is relieves for leaving the man ("I loved him when I left him" and "I had to tell him, I had to go"). This shows how the girl is leaving the man and feeling the need to go away from the man. At this point, a question can be raised: Where the girl will go? The answer of this question is obviously answered in the chorus of the song

Havana, ooh na-na (ay, ay)

Half of my heart is in Havana, oohna-na (ay, ay)

He took me back to East Atlanta, na-na-na (uh huh)

Oh, but my heart is in Havana (ay)

My heart is in Havana (ay)

Havana, ooh na-na
The preceding lines from the songs highlights how the girl longs for Havana, the capital of Cuba which is her hometown. She clearly stated her love to her place of origins ("Half of my heart is in Havana") and how bringing her to America does not change this feeling ("He took me back to East Atlanta, but my heart is in Havana"). Curiously, there are slight changes of lyric between the song's first chorus and the rest of the choruses (second and last) in the song. The one already stated in the above is the lyric used for second and third chorus. The first chorus can be read as follows

Havana, ooh na-na (ay)

Half of my heart is in Havana, oohna-na (ay, ay)

He took me back to East Atlanta, na-na-na

Oh, but my heart is in Havana (ay)

There's somethin' 'bout his manners (uh huh)

Havana, ooh na-na (uh)

Though only slight, it can be clearly seen that after the lyrics "but my heart is in Havana" the first chorus followed it by "There's somethin' 'bout his manners" while the second and last chorus of the songs followed by "My heart is in Havana." The slight differences is happening because the first chorus came before the first verse of the song which talks about the event how the speakers meet the man. That is why "There's somethin' 'bout his manners" is used to signify two things: to signify that the speakers father is right about the man ("And papa says he got malo in him") or that to explain the things that make the speaker fall in love with the men which is his manner. The latter can be seen from the fact that despite the girl said "But my heart is in Havana," she keeps discussing about the man's manner. The second and third chorus., which comes after the speaker break up the man, contains affirmation instead. After the speaker said "But my heart is in Havana," he affirms it once again by saying "My heart is in Havana." Further confirmation that her full heart is in Havana, not only half like in the second 
line of the chorus ("Half of my heart is in Havana.")

The bridge also provides some interesting remarks on how the girl wants to go back to Havana instead of staying in America, as it says

Ooh na-na, oh na-na-na (oo-ooh)

Take me back, back, back like

Ooh na-na, oh na-na-na (yeah, babe)

Take me back, back, back like

Ooh na-na, oh na-na-na (yea, yeah)

Take me back, back, back like

Ooh na-na, oh na-na-na (yea, babe)

Take me back, back, back

Take me back to my Havana...

The bridge uses many words of "Take me back," and ends the bridge with the word "take me back to my Havana." This means that although the speaker already settled in America, she remains longing for a return voyage to Havana as her heart is already settled there. Therefore, the speaker of the story admits that Havana is her cultural identity, a place for her to come home, and a place where her heart belongs to. No matter that she is already moved to America, she feels the need to go back to her origin as Cuban because her heart is already there.

\section{Relation between the Theme of the Song with Camila Cabello's Life}

In many ways, Camila herself resembles the speaker of her song. Camila was originally from Cuba and later on immigrated with her parents to America to find a better life. Cabello notes this event in her essay posted in POPSUGAR Website entitled "Our Dream were Bigger than Our Fears." In her essay, he describes how in dire need of better life her family needs to move to Unites States. At first, she feels that her family has leave everything behind in order to start a new in America. She feels that she lost her home, her bound with a place she calls home, which is Havana. However, the more she settled the more she realizes something.
I was wrong about one thing. My mamá and papá did not leave everything behind, they brought it with them. My grandma still makes pork and rice and beans every holiday like she did, and my mom still feels the waves of the malecón in her heartbeat because she still feels the most at peace when she's by the sea. My grandma and dad still get drunk and sing Luis Miguel in the kitchen.

And whenever we find another person from our country, we freak out. "¿De qué parte?" Because we have home in us. Because we brought it with us. Every Cuban brought it with them and so we have Miami. Mexicans brought it and so we have the best Mexican food ever. The Italians brought it and so we have pizza. The Swedish brought it and we have great pop songs. The list goes on and on. And so, that's why when I hear a bigoted, racist man with power and influence speak with anger and ill-will about immigrants, I think "what a fool." (Cabello, 2017)

In her essay, Cabello notes about one thing the she admits she was wrong: that she does not lost everything when she lives Havana with her family as her family bought it with them. She also notes how other immigrants brought their cultural elements with them making the place they live become more and more richer in culture. By this condition she feels that "home can be brought" even in the place where they are not originated from. This means that Cabello believes in the notion of ever-changing cultural identity, something can Bhabha and Hall already argues. The cultural identity is not tight upon the places and how the culture can influence each other and making even richer culture. Hence, the song "Havana" affirms with the concept of ambivalence.

\section{CONCLUSION}

From the analysis, it can be concluded that the songs "Havana" shows the character's longing of Cuban cultural identity in the character of the song despite being offered a life in America. This notion can be seen in the lyric when the character profoundly said that "My 
Heart is in Havana," Yet Cabello also affirms the ambivalence of a culture which is proposed by Bhabha. She recognizes that culture is not particularly linked with the place someone originated from but can be adapted with the present surrounding. Moreover, she also adds about the notion of mutual influence between cultures and how we should celebrate those things instead of lament it.

\section{REFERENCES}

Bhabha, H. K. (2003). Cultural Diversity and Cultural Differences. In B. Ashcroft, G. Griffiths, \& H. Tiffin (Eds.), The Postcolonial Studies Reader (pp. 206-209). New York: Routledge.

Cabello, C. (2017, April 8). Our Dreams Were Bigger Than Our Fears. Retrieved June 9, 2018, from POPSUGAR: https://www.popsugar.com/latina/Camila-Cabello-HerCuban-Background-42239921

Griffith, K. (2004). Biographical Criticism. In K. Griffith, Writing essays about literature: a guide and style sheet (pp. 177-178). Wadsworth: Wadsworth Publishing Company.

Guerin, W. L. (2005). A handbook of critical approaches to literature (5th ed.). New York: Oxford University Press.

Hall, S. (2015). Cultural identity and Diaspora. In L. Chrisman, \& P. Williams (Eds.), Colonial Discourse and Postcolonial Theory: A Reader (pp. 392-403). London and New York: Routledge. 